\title{
The Impact of Sincerity of Terrorists on Committing Terrorist Activities in Turkey
}

\author{
Ahmet Turer, Robyn Diehl McDougle \\ L. Douglas Wilder School of Government and Public Affairs, Virginia Commonwealth University, Richmond, \\ Virginia, USA \\ Email: rdmcdougle@vcu.edu
}

Received 24 July 2015; accepted 21 September 2015; published 24 September 2015

Copyright (C) 2015 by authors and Scientific Research Publishing Inc.

This work is licensed under the Creative Commons Attribution International License (CC BY). http://creativecommons.org/licenses/by/4.0/

(c) (7) Open Access

\section{Abstract}

Research Summary: This study explores the impact of sincerity of terrorists on committing terrorist activities in Turkey. One of the researchers is a Chief of Police in Turkey and has worked in the Anti-terror Department for a considerable part of his professional career. His professional experience has shown that the more sincere a terrorist is the more violent or heedless the terrorist activity is. Thus this research academically and statistically examines this observation and finds that sincerity affects the level of violence. Attachment and adherence to the terrorist organization turn even the characteristically non-violent people into blood seeking terrorists. Policy Implications: Terrorism is still one of the major challenges that the contemporary world faces today. Governments, policy makers, and other stakeholders have great difficulty identifying effective legal mechanisms for fighting terrorism, mainly because of uncertainties regarding both the targets and offenders of terrorist acts. The current study suggests two types of policy implementations. The first is to improve socioeconomic conditions so that people will be less vulnerable to terrorist recruitment, a tactic that requires the identification of risk groups. The second is to detect terrorists and their networks, a tactic that requires the use of different types of intelligence and preventive interventions in the locations that terrorists primarily use for recruitment. The former implementation is a long-term and large-scale project, whereas the latter one is a short-term, smallscale project that appears to be more promising. The two are, however, interrelated. Simply implementing the second tactic could prevent terrorism, but in the absence of the first tactic, terrorist groups will likely find other fertile ground in which to flourish.

\section{Keywords}

Terrorism, Sincerity/Fidelity, Turkey, Policy 


\section{Introduction}

Although terrorism became a popular subject and topic of academic interest after the incident of 9/11 in the US, the concept of terrorism is a neither new nor diminishing topic of public and professional attention of the Turkish government and Turkish National Police. Turkey has suffered immensely from terrorism over the last couple of decades; however understanding the dynamics of terrorism has not been of much academic concern in Turkey as opposed to fighting it through government forces. Academic studies in Turkey on terrorism limited both in number and scope mainly focused on reasons of terrorism, the relationship between socio economic dynamics and terrorism, the impact of migration on terrorism and finance of terrorism. However understanding the motives of terrorism and terrorist actions on an individual level is crucial in solving the equation. Thus, this research focuses on one of the important and yet unexplored territories within the domain of terrorism: the impact of sincerity.

\subsection{Terrorism in Turkey}

In the 1960s, Turkey was affected by terrorist activities of mainly leftist groups, which emerged in part as the result of resurgence of terrorism in Europe (Laqueur, 1999) [1]. Extremist left-wing ideologists began to commit terrorist activities after the dramatic failure of the Socialist Turkish Labor Party in the election of 1969, which resulted in public disorder and strikes. The government was unable to prevent the disorder in the country and lost control. In 1960, the armed forces took control over by declaring martial law. Military power ruled the government for an eighteen-month period and civil rule was restored in 1961 (Bal \& Laçiner, 2001 [2]; Laqueuer, 1999, p. 31 [1]). These events explain that the root causes of Turkish terrorism were the rapid urbanization and the resulting unequal distribution of economic resources. This leftist movement received support from Bulgaria and the eastern bloc countries. The right used religious institutions for the same purpose. During 1978 and 1979, over two thousand political murders were committed. Again in 1980, the military took the power to restore order within the country (Laqueur, 1999) [1].

In late 70's another face of terrorism demanding separation of south east of Turkey appeared using Kurdish population of Turkey. This was mainly in the non-urban areas (Laqueur, 1999) [1]. The Kurdish Workers Party (PKK) was a militant, separatist organization that aimed to create an independent Kurdish state in the southeastern part of Anatolia (Button, 1995) [3]. Although Turkish authorities have argued that there is no Kurdish problem in Turkey, Kurds have vigorously demanded more cultural, linguistic, and political rights. However, the reality shows that citizens of Kurdish ethnic heritage enjoy full rights as Turkish citizens (Ahmed \& Gunter, 2000 [4]; Keyman, 2007 [5]; Kirisci \& Winrow, 1997 [6]; Lytle, 1977 [7]; MacDonald \& O’Leary, 2007 [8]; Taspinar, 2005 [9]).

Terrorist acts have also been committed by extremist religious groups. Such groups have been trying to change the secular Kemalist reforms and replace a secular, constitutional Turkish state with an Islamic Sharia based state following the Iranian model (Laqueur, 1999) [1]. These groups enjoyed wide Iranian support and often acted on behalf of Iranian local and regional, political and strategic interests. The reaction of Turkish authorities in the past to Islamic terrorist activity was limited and thus encouraged leaders of these groups and their sponsors to continue escalating violence, hoping it will bring down the secular democratic regime in Turkey. In Turkey and by many observers abroad, the Kurdish Workers' Party (PKK) has been considered as the main threat to the Turkish state's national unity and defense.

The Islamic terrorist activity in Turkey dates back to 1960s. As early as 1967 and 1973, the leaders of Hizb-alTahrir (Islamic Liberation Party) were captured for attempting to bring the Islamic State Constitution to Turkey. Islamic Jihad emerged as a real terrorist threat in the 1980s, following a series of assassinations against Jordanian, Saudi and Iraqi diplomats. In October 1991, Islamic Jihad took responsibility for murdering an American military officer and wounding an Egyptian diplomat in order to protest the Middle East peace conference held in Madrid. For many years, it was thought that this organization was a Lebanese Shiite terrorist group; however it was later discovered that a functioning Turkish branch existed, engaging in terrorist activities.

In the Turkish Anti-Terrorism Act (April 12 $2^{\text {th }}$, 1991) terrorism is defined as follows: "Terror refers to all kinds of activities attempted by a member or members of an organization for the purpose of changing the characteristics of the Republic which is stated in the constitution, and the political, jurisdictional, social, secular, economic system, destroying the territorial integrity of the state and the government and its people, weakening or ruining or invading the authority of the government, demolishing the rights and freedom, jeopardizing the existence of 
Turkish government and Republic, destroying the public order or peace and security” (Turkish Government, 1991).

Counter Terrorism Department and Intelligence Department within Turkish National Police, distinguish three categories of terrorist groups: 1) Leftist Terrorist Organizations-most of these groups fall into Marxist-Leninist groups; 2) Separatist Groups-primarily PKK and its sub groups fall into this category; 3) Religiously Motivated Terrorist Groups — these groups include Turkish Hezbollah, IBDA-CE, Hizb-urTahrir, and Al-Qaeda.

\subsection{Theoretical Framework}

Terrorism is a crime. Like many other crimes, terrorism involves deviant behavior, which can be explained by various criminological theories. It is the author's view that a single theory is not capable of providing an adequate explanation of terrorism. Terrorism is a multi-dimensional phenomenon. Firstly, it is a social and cultural problem. Most terrorist conflicts arise from ethnic and heritage based conflicts. Secondly, regardless of ethnicity or social status, ideological dynamics play a role behind terrorism. Lastly, terrorism is simply as in the case of state terrorism. At the bottom line, terrorism involves an organized group of individuals acting towards a particular cause. Issues of ideological base, leadership, recruitment and retention of members should be addressed in the research along with questions regarding commitment of criminal activities of these groups.

Terrorism is not a pathological phenomenon. The resort to terrorism is not an aberration. The central focus of study ought to be on why some groups find terrorism useful, and in standard control theory fashion, why other groups do not find terrorism useful. Some groups may continue to work with established patterns of dissident action. Other groups may resort to terrorism because they have tried other alternatives. Still other groups may choose terrorism as an early choice because they have learned from the experiences of others, usually through the news media. Crenshaw (1998) [10] calls this the contagion effect, and claims that it has distinctive patterns similar to the copycat effect as in other theories of collective violence (Gurr, 1970) [11]. There may be circumstances in which a terrorist group wants to publicize its cause to the world-a process called the globalization of civil war.

Factors that influence the rational choice of terrorism include place, size, time, and the climate of international opinion. A terrorist plot in a democratic society is less likely to involve senseless violence than a scheme hatched under an authoritarian regime because under the latter, terrorists realize they have nothing to lose with the expected repercussions. Size is important because a small elite group is more likely to resort to terrorism when the population is passive. This means that more senseless acts of violence may occur in a stable society rather than in one on the verge of collapse. Time constraints are important because the terrorist group may be competing with other groups or attempting to manage a tit-for-tat strategy with counterterrorism.

The climate of international opinion, if low for the problems of the host country, may force terrorists to take action that risks a repressive counterterrorist reaction, in hopes that their suffering will capture public attention. In short, terrorism is an excellent tool for managing the political agenda on a world stage. The study of terrorism through the perspective of rational choice theory is still in its early stages. In recent years, a number of talented modelers have started to apply the analytical instruments of rational choice theory to explain terrorism.

The current study explores rational choice theory in the context of the role of sincerity/fidelity of terrorist on committing terrorist activities. Secondly, the study explores whether socio-economic status has any impact on recruitment and level of activities engaged in by the terrorists as well as whether ethnic affiliation and religious affiliation matter in level of violence exerted by terrorists.

\section{Data and Methods}

\subsection{Data Collection}

Five hundred different terrorists' testimonial reports were randomly selected from Turkish National Police database between 1999 and 2006. These cases represent PKK, Hezbollah, Ibda-C, Dev-Sol and Al-kaide terrorist groups. The corpus of texts was these five hundred testimonial reports. Unit of Analysis was individual cases from terrorist groups.

\subsection{Dependent Variables}

The dependent variable in this study was a measure of the activities done by the terrorists. This was a limited 
continuous variable ranging from the less violent activity to the most violent activity. The terrorists' criminal actions have been classified into categories. These categories were based on their own statements, which they gave to the Counter Terrorism Department during the interrogation after they were captured. Based on the terrorists' own statements, which were taken by the Counter Terrorism Department when they were captured, their criminal actions were classified into categories and thus the first part of the variable is formed.

A score was assigned to each terrorist depending on his or her activity in the organization. This will allow to make comparisons among terrorists. Each terrorist also gets scores from their activities in order to compare them to each other. For every year within the groups they will be scored by 10 points. If the terrorist has been in the organization for 5 years he or she will get 50 points, plus his or her terrorist activities will be count as each killing is 10 points, or each kidnapping is 6 points. This gives the researcher an opportunity to compare the new member to an older one.

As shown in Figure 1, the more violent and the more intense the activities, the higher the score of the terrorist.

\subsection{Hypotheses}

H1: There is a positive relationship between sincerity and level of violence.

Data collected by Turkish National Police (1996-2006) will be used to test this hypothesis based on the variables "Sincerity Level" and "Violence Level".

H2: The more educated terrorist has the more violent terrorist activities.

Data collected by Turkish National Police (1996-2006) will be used to test this hypothesis based on the variables "Education" and "Total Score".

H3: Males are the more likely to have more violent activities than the females.

Data collected by Turkish National Police (1996-2006) will be used to test this hypothesis based on the variables "Gender" and "Total Score".

H4: Singles are the more likely to have more violent activities than the married terrorists.

Data collected by Turkish National Police (1996-2006) will be used to test this hypothesis based on the variables "Marital Status" and "Total Score".

H5: Separatist group members are more likely to have more violent activities than the Leftists and Religiously Motivated terrorists.

\subsection{Independent Variables}

\subsubsection{Sincerity Level}

One of the concerns of the previous studies on the psychological dimensions of the terrorists was whether terrorists are already abnormal individuals. Further research indicated that not all terrorists are criminals (Silke, 2003) [12]. Thus the question of why normal, non-violent individuals resort to violence when they become a member of the terrorist organization. If they start normal and later become violent then the personality traits of terrorists would be highly irrelevant. Studies show that terrorist groups do not specifically seek out criminals like gangs do (Jenkins, 2011 [13]; Klein, 2005 [14]; Lennings, Amon, Brummert, \& Lennings, 2010 [15]; Miller \& Mills, 2010 [16]; Stahl, 2006 [17]), and obviously the group’s normative structure facilitates criminal activity.

In that sense, organizational attachment and blind adherence are left as an explanation. Sincerity in this study is used as a measure of attachment and adherence. Sincerity variable is derived from the statements with content analysis technique. If the terrorist is mentioning the Turkish Government as different country and feels like he or

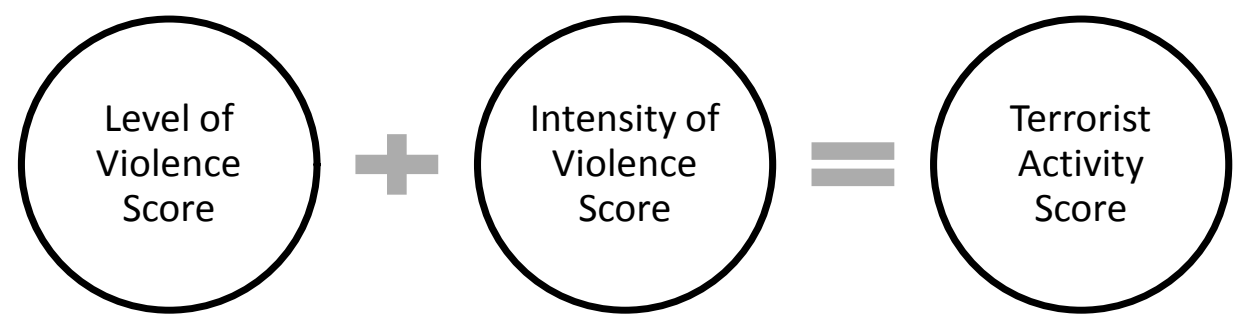

Figure 1. Measure of terrorist activity. 
she does not belong to it, s/he is considered as sincere, otherwise he or she will be considered as insincere. If the person does not fall into any category, he or she was treated as ambiguous.

\subsubsection{Recruitment and Group Related Variables}

The question of how and through whom individuals contact terrorist organizations and become a member has been one of the concerns of the existing terrorism literature. Terrorist groups' social networks, as well as individuals' close circles are believed to play an important role in recruitment process. In this regard, as a similar group in terms of their group dynamics, associations in youth gang groups play a central role in becoming involved with the criminal group. For instance, having delinquent peers and having an existing family member in the gang were some of the statistically most reliable indicators of gang involvement. Studies indicate that terrorists extensively use social networks for recruitment (Crenshaw, 1998 [10]; Ekici, 2006 [18]; Laqueur, 1999 [1]; Silke, 2003 [12]). Friendship and family networks as well as legal organizational associations are the major tools used by terrorist organizations to reach out to potential recruits (Ekici, 2006) [18].

Length of membership in the Group was used to capture this variable and was self-reported.

\subsubsection{Reason for Joining the Group}

This is a nominal variable broken into dichotomus variables. In the interview the terrorists are asked to choose between 5 choices for reasons for joining the group (just curiosity, personal motivations, socialization, inadequate family supervision, low income). As a reference group personal motivations is left out.

\subsubsection{Education Level}

Education level is a categorical variable where the lowest category signifies lowest level of education. This variable ranges from 1 to 5 .

1) Age

This variable is a continuous variable and calculated as of the date of the interview.

2) Gender

This is a dichotomous variable where the reference group is females (value is zero).

3) Marital Status

This is a dichotomous variable where the reference group is non-married (value is zero).

4) Occupational Status

This is a dichotomous variable where the reference group is non-working (value is zero).

5) Economic Status

This is a categorical variable, where the lowest category signifies lowest level of education. This variable ranges from 1 to 5 .

\subsubsection{Ethnicity}

This is a dichotomous variable where the reference group is Turk (value is zero).

\subsubsection{Religious Affiliation}

This is a dichotomous variable where the reference group is Sunni (value is zero).

\section{Statistical Analysis \& Results}

\section{Characteristics of the Terrorist Group}

The interviews showed that the most of the candidate and convicted terrorists are males with a percentage of $81 \%$. Most of the terrorist organizations in Turkey have many legally established youth clubs and culture houses that provide social environments and activities for high school and college level students, where students from the opposite sex meet and establish new relationships. The study samples also showed that the majority of the terrorists are ethnically Turks. Convicted terrorists were found to be predominantly Turkish (89\%), whereas the Turks made up only 55\% of the candidate terrorists (see Table 2).

While ethnicity is not a determinant factor in the selection process for some terrorist organizations, PKK solely recruits Kurds. While by itself not an ethnical affiliation, being an Alevi in terms of religious belief is also considered as a separate ethnical group as this faith is followed only by a certain group. Due to the difference in 
their religious beliefs and due to the notion that they are being discriminated against, Alevi community members are ideal recruits for terrorist organizations (see Table 2).

Some terrorist organizations abuse the Alevi community as a tool for their goals due to the left-oriented worldview of this community. In some cases, even those who are not Aleviare shown as Alevis by the terrorist organizations when they are killed in terrorist attacks or police/military operations. Organizations agitate Alevi community during the terrorist funerals. They publicize that the Alevi community in Turkey is suppressed and discriminated against. Thus, the Alevi community becomes more prone for new recruits.

One of the common characteristics of the candidate and convicted terrorists is their marital status. Eighty-eight percent of the candidate terrorists and $67 \%$ of the convicted terrorists were never married. In most terrorist organizations, marriage is only allowed for camouflaging purposes, which is generally referred to as "revolutionary marriage" inside the organizations.

Statistics show that the majority of terrorists have chosen to move from their original birthplace to another city. Sixty percent of the candidate terrorists and $79 \%$ of the convicted terrorists moved from their original birth place to the big cities to improve their quality of life, especially for job and education opportunities.

When we look at the statistics, we observe some differences between convicted and candidate terrorists in terms of several attributes. Candidate terrorists are more educated with $37 \%$ university or higher education than convicted terrorists are with $11 \%$. In terms of job status, most of the convicted terrorists have a full-time or part-time job compared to candidate terrorists (56\% and $14 \%$ respectively) (see Table 1).

While descriptive statistics tell a lot, when it comes to causal relationships they may be misleading, or simply cannot go beyond the obvious. As the name suggests descriptive statistics merely describes what is in hand but when we are interested in determining relationships between two variables and single out spuriousness out of the link, we need multivariate statistical analyses (see Table 1).

Before deciding on the final models, regular multiple regression diagnostics for outliers, non-linearity, heteroskedasticity, and multi-collinearity were completed using appropriate procedures. ${ }^{1}$ Since age and years spent in the organization were highly correlated and thus created a collineraity problem, age was not included in the analyses due to high collinearity. ${ }^{2}$

Table 1. Characteristics of the candidate and convicted terrorists.

\begin{tabular}{lcc}
\hline Characteristics & Candidate Terrorists & Convicted Terrorists \\
\hline Male (\%) & 7 & 83 \\
Turk (\%) & 51 & 88 \\
Alevi (\%) & 92 & 81 \\
Never married (\%) & 88 & 67 \\
Mobility (\%) & 60 & 79 \\
Education (\%) & 13 & 41 \\
$\quad$ Primary and less & 55 & 51 \\
Secondary and high & 31 & 9 \\
University and upper & & 51 \\
Job status (\%) & 13 & 17 \\
Full-time or part-time & 30 & 17 \\
Temporarily not working & 51 & 15 \\
Unemployed & 5 & 18
\end{tabular}

\footnotetext{
${ }^{1}$ No influential cases were detected in all of the models. Partial regression plots revealed linearity in models. As mentioned in tables robust standard errors were estimated to correct for heteroskedasticity.

${ }^{2}$ In cases when the variance inflation factor (VIF) is less than 10 and/or the tolerance (1/VIF) is larger than 0.1, no multi-collinerarity is assumed (Belsley, Kuh, \& Welsch, 1980; Greene, 2003).
} 
Table 2. Descriptive statistics.

\begin{tabular}{lccccc}
\hline \multicolumn{1}{c}{ Variable } & N & Mean & Std. Dev. & Min & Max \\
\hline $\begin{array}{c}\text { Dependent Variable } \\
\text { Terrorist activity }\end{array}$ & 500 & 160.86 & 219.55 & 1.00 & 1150 \\
Explanatory Variable & & & & \\
Sincerity & 500 & 0.009 & 0.383 & -1 & 1 \\
Control Variables & & & & \\
Age & 500 & 22.994 & 18.391 & 17 & 58 \\
Gender (male) & 500 & 0.817 & 0.387 & 0 & 1 \\
Marital status & 500 & 0.708 & 0.456 & 0 & 1 \\
Level of education & 500 & 0.385 & 0.751 & 1 & 5 \\
Occupational status & 500 & 0.509 & 0.738 & 0 & 1 \\
Ethnicity (Kurdish) & 500 & 0.217 & 0.567 & 0 & 1 \\
Religious affiliation (Alevi) & 500 & 0.301 & 0.497 & 0 & 1 \\
Economic status & 500 & 0.459 & 0.674 & 1 & 5 \\
Length of membership & 500 & 19.744 & 21.425 & 1 & 45 \\
Curiosity & 500 & 0.196 & 0.674 & 0 & 1 \\
Socialization & 500 & 0.246 & 0.525 & 0 & 1 \\
Inadequate supervision & 500 & 0.178 & 0.298 & 0 & 1 \\
Low income & 500 & 0.312 & 0.502 & 0 & 1 \\
Status (convicted) & 500 & 0.478 & 0.389 & 0 & 1 \\
Separatist & 500 & 0.413 & 0.367 & 0 & 1 \\
\hline
\end{tabular}

The cross-sectional data analysis results show that as sincerity increases the level of violence also increases. Thus, the main alternative hypothesis that whether sincerity affects the level of terrorist action is retained. Also the regression analysis shows that the more educated a terrorist is the more intense the level of violence that she or he would exercise. The results show no significant relationship between males and females and between singles and married terrorists in terms of level of violence (see Table 3).

Another important result is that there is a significant relation between the type of terrorist group and the level of violence. Separatists are more violent than Leftists or Radical Islamists.

The cross-sectional data analysis results show that as sincerity increases the level of violence also increases. Thus, the main alternative hypothesis that whether sincerity affects the level of terrorist action is retained. As well, the regression analysis shows that the more educated a terrorist is the more intense the level of violence that she or he would exercise. The results show no significant relationship between males and females and between singles and married terrorists in terms of level of violence. Finally, there is a significant relation between the type of terrorist group and the level of violence. Separatists are more violent than Leftists or Radical Islamists (see Table 3).

\section{Discussion \& Policy Implications}

Terrorism can flourish as long as new recruits are added to terrorist organizations. Therefore, the future of terrorism depends on a successful terrorist recruitment and continuation of the attachment to the organization. The current study found important correlates for terrorist recruitment, as well as the process and the decision making of terrorist organizations in recruitment. Also how the sincerity of the organization members affects their attachment to the terrorist organization is tested. Before discussing the findings regarding each of the research questions, a few points should be clarified.

First, the recruitment process of the terrorist organizations is predominantly informal. Despite the submission of personal information to the terrorist organizations as an indicator of formal recruitment process, there is no formal cutoff point during acceptance to the organization. Recruitment is a long process that requires consistent commitment to both violent and nonviolent group activities. After months or years of involvement with the terrorist group an individual is accepted to the cell house of the terrorist organization. 
Table 3. Regression analysis of terrorist activity index.

\begin{tabular}{|c|c|c|c|}
\hline & Model-1 Bivariate & Model-2 Recruitment & Model-3 Full Model \\
\hline Explanatory Variables & Coefficients & Coefficients & Coefficients \\
\hline Sincerity & $0.38^{* * * *}(0.06)$ & $0.31^{* * * *}(0.06)$ & $0.29^{* * * *}(0.06)$ \\
\hline \multicolumn{4}{|l|}{ Control Variables } \\
\hline Length of membership & & $0.13(0.28)$ & $-0.01(0.24)$ \\
\hline Curiosity & & $0.16(0.1)$ & $0.17(0.14)$ \\
\hline Socialization & & $0.21(0.15)$ & $-0.12(0.18)$ \\
\hline Inadequate supervision & & $-0.02(0.01)$ & $-0.03^{* *}(0.01)$ \\
\hline Low Income & & $0.03(0.1)$ & $-0.06(0.1)$ \\
\hline Separatist & & $-0.03^{* *}(0.01)$ & $-0.03^{* *}(0.01)$ \\
\hline Age & & & $-0.11(0.08)$ \\
\hline Gender (male) & & & $-0.01(0.05)$ \\
\hline Marital status & & & $-0.21(0.12)$ \\
\hline Level of education & & & $0.34^{* * *}(0.14)$ \\
\hline Occupational status & & & $0.86^{* *}(0.31)$ \\
\hline Ethnicity (Kurdish) & & & $-0.01(0.24)$ \\
\hline Religious affiliation (Alevi) & & & $-0.4(0.24)$ \\
\hline Economic status & & & $-0.04(0.24)$ \\
\hline Status (Convicted) & & & $0.39^{*}(0.18)$ \\
\hline Constant & $4.79(6.17)$ & $-4.04(5.41)$ & $7.54(4.04)$ \\
\hline $\mathrm{N}$ & 500 & 497 & 492 \\
\hline $\mathrm{F}$ & $57.25^{* * *}$ & $49.99^{* * *}$ & $22.11^{* * *}$ \\
\hline $\mathrm{R}^{2}$ & 0.77 & 0.76 & 0.52 \\
\hline
\end{tabular}

Significance levels based on a one-tailed test: ${ }^{* * *} \mathrm{p}<0.001,{ }^{* *} \mathrm{p}<0.01,{ }^{*} \mathrm{p}<0.05$. Robust standard errors in parenthesis.

The second point is the freedom of choice in recruitment. The question of whether terrorist recruitment is a result of popular and unshakable support for terrorist activities or is an involuntary choice due to coercive external socioeconomic conditions is the main question here. The results of this research show that freedom of choice in recruitment thus sincerity should be accepted as the general rule, because there are many opportunities available to avoid joining the terrorist organizations. One piece of evidence for such freedom of choice in recruitment can be derived from the high percentages of mobility among Hezbollah terrorists. Those not volunteering to join the terrorist groups migrated to the western parts of Turkey from the Hezbollah and the PKK operating areas in the eastern and southeastern parts of the country (Ekici, 2006) [18].

Third, without an opportunity to access the terrorist group, an individual cannot become a terrorist (Silke, 2003) [12]. An opportunity for accessing a terrorist organization can occur in two ways. A terrorist candidate must identify an accessible avenue into the group, or else the terrorist organization has to make that opportunity available to new members through various ways. If using the first method, an individual faces several risks and difficulties. First, terrorist groups almost always operate underground. Therefore, it is difficult to search them out. Second, even if a candidate can find an avenue to the terrorist organization, he or she risks coming across the wrong people or security forces. If using the second method, however, the terrorist organization can use a legal political or social organization to make contact, which is more efficient when the candidate shares the same ideology with the terrorist group and possesses the desired characteristics. Candidate terrorists must demonstrate their commitment to the organization's goals and ideology by participating in various illegal activities such as protests.

\subsection{Policy Implications}

Terrorism is still one of the major challenges that the contemporary world faces today. Governments, policy makers, and other stakeholders have great difficulty identifying effective legal mechanisms for fighting terrorism, mainly because of uncertainties regarding both the targets and offenders of terrorist acts. 
According to the literature on terrorism, there is no single policy paradigm for counterterrorism. The policies offered include hardening potential terrorist targets, punishing terrorist acts for deterrence, and gathering information regarding terrorists and terrorist networks through intelligence-based interventions.

However, as mentioned before, due to the limitations of terrorism research, evidence-based policies are rare. For instance, some researchers made comparisons between the GDP (Gross Domestic Product), the educational level of a country, and the number of terror incidents or active terrorist groups to identify working policies against terrorism. Despite the fact that these studies might offer some insight, types of terrorist activity, profiles, and ideologies vary. Therefore, there is a demand for micro-level studies in order to develop effective policies.

The current research is a micro-level study that attempts to identify effective policies against main terrorist groups from Turkey. Because terrorists groups vary in their tactics, target selection, and ideologies, understanding attachment and further preventing recruitment to terrorist groups are believed to be one of the most effective terrorism prevention methods. To this end, this study suggests macro-level implementations that can be employed by the government and micro-level implementations that can be used by law enforcement agencies to prevent terrorism and terrorist recruitment.

This study suggests two types of policy implementations. The first is to improve socioeconomic conditions so that people will be less vulnerable to terrorist recruitment, a tactic that requires the identification of risk groups. The second is to detect terrorists and their networks, a tactic that requires the use of different types of intelligence and preventive interventions in the locations that terrorists primarily use for recruitment. The former implementation is a long-term and large-scale project, whereas the latter one is a short-term, small-scale project that appears to be more promising. The two are, however, interrelated. Simply implementing the second tactic could prevent terrorism, but in the absence of the first tactic, terrorist groups will likely find other fertile ground in which to flourish.

\subsection{Implications, Limitations and Future Research}

Self reports are useful when the researcher attempts to collect detailed information about individuals and the sociological, psychological, and environmental factors that affect an individual's behavior (Thornberry \& Krohn, 1994); however, it is commonly believed that self reports have many flaws, such as under- or over-reporting, response falsification, bias-associated recall errors, the testing (interview) effect, and so on. Having mentioned the general limitations of self reports, the limitations of the data used in this research need to be considered as well. The interviews contain limited information; therefore the reasons why terrorist organizations preferred certain individuals or what kinds of criteria they used for recruitment decisions are not precisely known. Generalizability is the last concern. Although current research collected samples from different regions of Turkey where terrorist groups operate actively, there are many other locations from which samples can be collected. Similarly, the ability to generalize the findings of this research to other terrorist groups operating in different countries needs to be investigated.

\section{Acknowledgements}

The authors are grateful to the Turkish National Police for the access to the data.

\section{References}

[1] Laqueur, W. (1999) The Age of Terrorism. Little, Brown, Boston.

[2] Bal, I. and Laçiner, S. (2001) Challenge of Revolutionary Terrorism to Turkish Democracy, 1960-80. Terrorism and Political Violence, 13, 23-36. http://dx.doi.org/10.1080/09546550109609701

[3] Button, S.H. (1995) Turkey Struggles with Kurdish Separatism. Military Review, 75, 70-83.

[4] Ahmed, M.M.A. and Gunter, M.M. (2000) The Kurdish Question and International Law: An Analysis of the Legal Rights of the Kurdish People. Ahmed Foundation for Kurdish Studies, Oakton.

[5] Keyman, E.F. (2007) Remaking Turkey: Globalization, Alternative Modernities, and Democracy. Lexington Books, Lanham.

[6] Kirisci, K. and Winrow, G.M. (1997) The Kurdish Question and Turkey: An Example of a Trans-State Ethnic Conflict.; Frank Cass, London.

[7] Lytle, E.E. (1977) A Bibliography of the Kurds, Kurdistan, and the Kurdish Question. Council of Planning Librarians, 
Monticello.

[8] MacDonald, C.G. and O’Leary, C. (2007) Kurdish Identity: Human Rights and Political Status. University Press of Florida, Gainesville.

[9] Taspinar, O. (2005) Kurdish Nationalism and Political Islam in Turkey: Kemalist Identity in Transition. Routledge, New York.

[10] Crenshaw, M. (1998) The Logic of Terrorism: Terrorist Behavior as a Product of Strategic Choice. Woodrow Wilson Center Press, New York.

[11] Gurr, T. (1970) Why Men Rebel? Princeton University Press, Princeton.

[12] Silke, A. (2003) Becoming a Terrorist. In: Silke, A., Ed., Terrorists, victims and Society: Psychological Perspectives on Terrorism and Its Consequences, John Wiley \& Sons, West Sussex. http://dx.doi.org/10.1002/9780470713600.ch2

[13] Jenkins, B.M. (2011) Stray Dogs and Virtual Armies: Radicalization and Recruitment to Jihadist Terrorism in the United States since 9/11. RAND, Santa Monica.

[14] Klein, N. (2005) Terror’s Greatest Recruitment Tool. Nation, 281, 14.

[15] Lennings, C.J., Amon, K.L., Brummert, H. and Lennings, N.J. (2010) Grooming for Terror: The Internet and Young People. Psychiatry, Psychology \& Law, 17, 424-437. http://dx.doi.org/10.1080/13218710903566979

[16] Miller, D. and Mills, T. (2010) Counterinsurgency and Terror Expertise: The Integration of Social Scientists into the War Effort. Cambridge Review of International Affairs, 23, 203-221. http://dx.doi.org/10.1080/09557571.2010.481664

[17] Stahl, R. (2006) Have You Played the War on Terror? Critical Studies in Media Communication, 23, 112-130. http://dx.doi.org/10.1080/07393180600714489

[18] Ekici, N. (2006) Ethnic Terrorism and the Case of PKK. Masters, Rutgers, New Jersey. 


\section{Appendix}

\section{Questionnaire}

1. What is your age?

2. Where were you born?

3. What is your gender?
A. Male
B. Female

4. Your marital status ( )
A. Single
B. Married
C. Divorced

5. What is your level of education? ( )
A. Secondary (lower, incomplete)
B. Secondary
D. Higher
E. Candidate of Sciences
C. Higher (incomplete)

6. Occupation/Profession

7. Occupational category ( )
A. Employed
B. Unemployed

8. What is your ethnicity?

9. How many siblings do you have?

10. How would you describe your family's economic situation? ( )
A. Very Poor
B. Poor
C. Average
D. Rich
E. Very Rich

11. What is your family's political background?
A. Left wing
B. Right wing close to center
C. Center
D. Left wing close to center
E. Left wing

12. What is your terrorist organization that you belong to? ( )
A.DHKP/C (Left)
B. Turkish Hezbollah (Right)
C. PKK (Separatist)

13. Do you have any relatives who work in the police or army force? ( )
A. Yes
B. No

14. Do you have valid passport ( )
A. Yes
B. No

15. Have you ever been abroad? ( )
A. Yes
B. No

16. Can you speak any foreign language? ( )
A. Yes
B. No

17. Do you know how to use a gun? (
A. Yes
B. No

18. Where did you get in touch with terrorist organization at first? ( )
A. School
B. Family gathering
C. Religious Compound
D. Prison

E. Political meeting or event F. Other (Please explain)

19. What was your relation to the person who gets in touch with you at first? ( )
A. Friend
B. Relative
C. Clergy
D. Teacher

E. Other (Please explain)

20. What was the gender of the person who gets in touch with you at first? ( )
A. Male
B. Female

21. What was age of the person who gets in touch with you at first?

22. How did the recruiters contact with you? ( )
A. Individually
B. Newspaper advertisements
C. Internet
D. Friend/relative advice
E. Other (Please explain)
When did you get in touch with the organization initially?

23. What was your age?

24. Which season ( )
A. Autumn
B. Winter
C. Spring
D. Summer

25. Daytime or nighttime? ( )
A. Day Time
B. Night Time 
26. What was the basic reason that causes you to go with terrorist organization? ( )
A. Just curiosity
B. Personal motivations (i.e. ego, sex or the lust for power)
C. Socialization from peers or the organization
D. Inadequate supervision of family
E. Low income
F. Other (Please explain) 